\title{
Kepemimpinan Nyai di Pesantren Al Hajar Kapurejo Pagu Kediri
}

\author{
Nailal Muna ${ }^{1}$ Hamam $^{2}$ \\ 1,2Institut Agama Islam Tribakti Kediri \\ 1numa72@gmail.com, 2 hamamsyamsuri@gmail.com,
}

\begin{abstract}
Abstrak
Penelitian ini dibingkai dalam topic kepemimpinan, yang secara khusus membahas kepemimpinan pengasuh perempuan di Pesantren Al Hajar Kapurejo Pagu Kediri dalam mempertahankan tradisi pendidikan pesantren sebagai lembaga tafaqquh fi addin. Penelitian ini terfokus pada bagaimana strategi pengelolaan pesantren, bagaimana kecenderungan gaya kepemimpinan nyai di pesantren, dan peran nyai di pesantren al Hajar Kapurejo Pagu. Jenis penelitian ini adalah penelitian kualitattif dengan pendekatan studi kasus. Teknik pengumpulan data dengan wawancara yang didukung dengan pengamatan dan dokumentasi. Analisis data dengan cara reduksi data. Akhir penelitian ini menunjukkan:Strategi pengelolaan pesantren dilakukan dengan perencanaan di awal tahun ajaran, pengorganisasian dalam kehidupan sehari-hari dan pengawasan langsung oleh nyai. Gaya kepemimpinan nyai cenderung mengedepankan orienasi kerja atau otoriter. Peran Nyai adalah sebagai pendidik yang diwujudkan dengan terjun langsung mengajar.
\end{abstract}

Kata Kunci: Pesantren, Nyai, Kepemimpinan

\section{Pendahuluan}

Pengasuh pesantren atau kyai ${ }^{1}$ sebagai leader sangat menentukan kualitas santri. Kiai penentu arah pendidikan pesantren, umumnya segala kurikulum pendidikan di pesantren tergantung pada kebijakan kiai. Selain sosok kyai, keberadaan pengasuh

1 Pengasuh atau biasa disebut kiai adalah salah satu unsur pesantren. Dalam teori Zamakhsari Dhofier ada empat komponen suatu lembaga dapat disebut pesantren, yaitu masjid, perempuan atau nyai juga mempunyai peranan penting dalam kehidupan pesantren, tetapi keberadaan nyai selama ini tidak begitu tampak. Keberadaan nyai kadang kala hanya sebagai pengasuh ke dua setelah kyai. Padahal peran seorang nyai tak kalah penting dengan kiai

pembelajaran kitab kuning, santri, dan kiai. Lihat Zamakhsyari Dhofier, Tradisi Pesantren (Jakart: LP3S, 1982) , hlm 44 
sebagai pemangku kebijakan dan mampu menjadi pemimpin yang efektif penentu dari kualitas sebuah pesantren. di kelompoknya. Tapi, sesulit apapun

Tetapi pasca reformasi kiprah nyai atau serumit apapun bidang kajian ini pesantren mulai diakui dan serta upaya melahirkan pemimpin yang diperhitungkan keberadaannya. Sosok efektif, selalu ada pegangan sejumlah nyai tidak hanya sebatas bayang-bayang kebesaran kiai, tetapi nyai juga mempunyai kiprah tersendiri dalam pendidikan di pesantren. Pengakuan tersebut adalah imbas dari gerakangerakan pemberdayaan perempuan yang banyak didengungkan oleh banyak kalangan. Kajian tafsir beberapa ayat al Qur'an yang dinilai misigonis juga mengalami perubahan, bahkan Nahdlatul Ulama sebagai organisasi kemasyarakatan yang berbasis pesantren dalam hasil kemutusan Muktamar ke 30 di Lirboyo juga mengakui dan membolehkan perubahan kajian tafsir ayat-ayat al Qu'an yang bersifat misigonis disesuaikan dengan tuntutan zaman.

Kepemimpinan merupakan bidang kajian yang lebih rumit karena seorang pemimpin berhadapan dengan daftar persyaratan yang semakin panjang sebelum ia mendapati dirinya teori yang membimbing orang menuju pengetahuan dan praktek kepemimpinan yang bermanfaat. ${ }^{2}$

Penelitian ini bermaksud mengungkap peran nyai dalam tradisi pesantren. Penelitian ini dilakukan di pesantren Salafiyah al Hajar Kapurejo Pagu Kediri. Hal ini menarik diteliti, karena melihat berbabagi keberhasilan yang diperoleh santri Pesantren al Hajar, misalnya meraih penghargaan Musabaqah Qiraatil Kutub (MQK) tingkat Kabupaten Kediri, dan ajang perlombaan santri yang diadakan Rabithah Ma'ahid Islamiyah (RMI) Pondok Putri Kabupaten dan Kodya Kediri. Tetapi asumsi yang muncul di masyarakat tersebut tumbuh karena kepercayaan terhadap figure ibu nyai, sosok nyai di pesantren al Hajar lebih terkenal daripada sosok sang kyainya.

$$
\text { Metode penelitian yang }
$$
digunakan dalam penelitian ini adalah 
metode kualitatif dengan pendekatan studi kasus, dengan tujuan untuk mengetahui fenomena yang terjadi pada subjek penelitian ${ }^{3}$ yaitu pesantren al Hajar. Sumber pokok dalam penelitian ini adalah pengasuh perempaun dari pesantren sebagai sumber primer, pengurus pesantren, santri dan masyarakat sekitar sebagai pendukung atau data sekunder. Proses pengumpulan data dengan wawancara kepada sumber primer dan sumber sekunder, pengamatan terhadap sumber primer dan sekuunder, dan dokumentasi kegiatan. Teknis analisis data dengan reduksi data, dan pengecekan keabsahan data dengan metode Triaggulasi.

Penelitian pendahalu yang digunakan adalah Pesantren dan Kepemimpinan Perempuan, Studi Kasus di PEsantren Al Badriyah Al Hikmah Purwoasri Kediri, Tesis karya Maria Ulfa Program PAscasarjana Universitas Kristen Satya Wacana. Pembeda dari penelitian ini, adalah penelitian Maria lebih banyak kepada teori gender, tanpa memasukkan teori kepemimpinan.

\section{Kajian Kepemimpinan}

Pemimpin atau kepemimpinan merupakan suatu proses dengan berbagai cara mempengaruhi orang atau sekelompok orang untuk mencapai suatu tujuan bersama" 4 .Pemimpin acapkali menjadi penentu suatu kebijakan yang ada dalam kelompok atau organisasi. Dalam kenyataannya pemimpin selalu identik dengan orang yang mempunyai kelebihan daripada yang lain. Hal itu kadang kala memunculkan suatu persepsi bahwa keberhasilan kerja suatu organisasi atau kelompok ditentukan oleh pemimpinnya. Jika program kerja kelompok berhasil maka keberhasilan tersebut dianggap sebagai keberhasilan seorang pemimpin. Karena itu seorang pemimpin harus memiliki kharisma yang dapat mempengaruhi untuk mencapai tujuan yang dikehendaki.

$$
\text { Selain kharisma sebagai }
$$

pembawaan lahir, gaya kepemimpinan seseorang juga akan berpengaruh terhadap hasil kerjanya. Lima gaya kepemimpinan berikut merupakan teori yang seringkali dikemukakan, yaitu pertama Gaya kepemimpinan laissez faire 
di mana pemimpim memberikan kebebasan kepada anggotanya dalam berbuat sesuatu. Pemimpin membiarkan anggotanya bekerja dan berkegiatan sendiri. Semua pekerjaan dan tanggung jawab menjadi agenda anggota kelompok, pemimpin tidak berpartisipasi dan hanya menjadi symbol saja. Kedua Gaya kepemimpinan kekeluargaan, di mana pemimpin mau dengan senang hati mendengarkan suara bawahannnya. Perilaku kepemimpinan lebih mementingkan nilai kekompakan daripada produktivitas hasil kerja. Dalam teori kekeluargaan ini, keakraban, dan suasana kebersamaan lebih di utamakan, sebagaimana sebuah keluarga. Ketiga Gaya kepemimpinan otoriter, di mana pemimpin mementingkan hasil dan produktivitas kerja, tetapi sangat rendah dan tidak pernah memperhatikan kekompakan anggota kelompok. Pemimpin adalah pemain tunggal dalam setiap keputusan yang dihasilkan, sedangkan anggota hanya sebagai pelaku dari keputusan pemimpin tanpa mempunyai hak untuk bicara. Keempat Gaya kepemipinan demokratis, seorang pemimpin demokratis akan sangat tinggi perhatiannya pada hasil kerja dan produktivitas kelompok, tetapi di sisi lain pemimpin juga memperhatikan kekompakan anggotanya, serta mengembangkan partisipasi anggotanya. Kelima Gaya kepemimpinan jalan tengah, Yaitu gaya kepemimpinan yang secara memadai mempertimbangkan keseimbangan orientasi yang situasional dengan target kepuasan anggota kelompok serta sasaran produktifitas tercapai. Gaya kepemimpinan ini tidak terlampau memberikan titik tekan kepada bawahan, dan dalam bersikap atau bersosial, pemimpin mencoba menciptakan hubungan pribadi dengan bawahannya akan tetapi tidak terlalu mencolok dalam sikap tersebut ${ }^{5}$.

Dalam sebuah organisasi salah satu dari kelima gaya tersebut, akan digunakana oleh pemimpin, kecenderungan gaya dari pemimpin akan tampak dalam kehidupan sehari-hari sebuah organisasi. Kecenderungan gaya kepemimpinan seseorang akan disesuaikan dengan situasi dan kondisi sebuah organisasi, adakalanya seorang 
pemimpin harus bersikap otoriter, dan tasawuf yang berisi nilai-nilai adakalanya harus bersikap demokratis, karakter.

adakalanya harus bersikap kekeluargaan.

Tidak bisa dikatakan bahwa salah satu sikap kepemimpinan lebih baik dari sikap yang lain, walaupun kadang kala asumsi yang muncul di masyarakat bahwa demokratis adalah sikap yang terbaik, tetapi kadang kala tidak juga demikian, kadangkala pemimpin harus bersikap yang lain, jika situasi menghendaki.

\section{Kepemimpinan Pesantren}

Sudah jamak diketahui, bahwa pesantren merupakan sebuah lembaga pendidikan tua di Indonesia. Banyak pesantren yang berdiri sebelum adanya proklamasi kemerdekaan Repubik Indonesia. Sejarah kemunculan pesantren sudah banyak dilakukan penelitian. Pesantren merupakan lembaga tempat orang-orang menempa diri untuk mendapatkan pengetahuan agama. Dalam pesantren-pesantren salaf, seorang santri (istilah untuk pelajar pesantren), akab belajar beberapa cabang keilmuan, seperti fiqh yang berisi hokum agama, tahuid yang berisi ajaran teoligi,

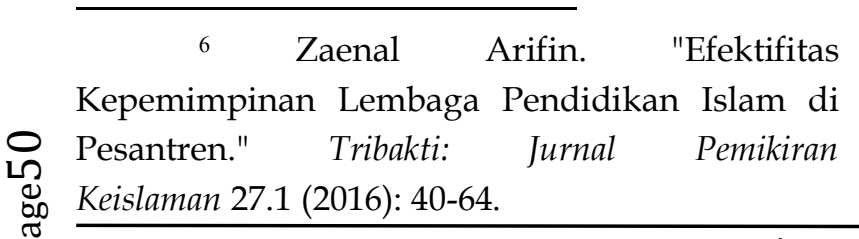

Pengembangan Pondok PEsantren", dalam A Hilmim dkk (ed), Manajemen PEsantren, (Yogyakarta: Pustaka PEsantren, 2005) hlm 77 
pemimpin tradisional yang mempunyai beberapa komponen kebiasaan dan sifatsifat yang menjadi syarat seorang pemimpin, ${ }^{8}$. Kelebihan yang dimiliki seorng kyai, bisanya adalah kemampuan persoalan ilmu agama, terutama kemampuan dalam memahami kitab kuning. Selain unggul dalam penguasaan kitab kuning, seorang kyai biasanya juga merupakan seorang tokoh tarekat, sering kali seorang kyai memeliki jama'ah dzikir yang beranggotakan masyarakat sekitar.

Melalui kelebihan-kelebihan itu seorang kiai dapat mengarahkan sebuah perubahan di lingkungannya, baik pesantren, ataupun masyarakat sekitar pesantren. Kiai pada pesantren dengan model salaf memegang kunci dari pesantren, setiap keputusan yang diambil oleh pesantren nota bene adalah keputusan seorang kiai. Segala bentuk pendidikan, kurikulum pendidikan, semua terletak pada tangan kiai.

Pengaruh dan kharisma kiai di pesantren dan ketaatan santri kepada kiai, selain karena kiai adalah guru, pemimpin, dan pemilik pesantren, juga karena konsep kitab Ta'lim al Muta'allim,

8 Ahmad Susilo, Strategi Pengembangan Pondok Pesantren, (Jakarta: Moyo SEgoro, 2003), hlm 147

\section{Peran Kepemimpinan Perempuan di Pesantren}

Nyai sebagai istri kiai dalam pandangan masyarakat mempunyai kedudukan yang tinggi. Kedudukan sosial itu dapat lebih meningkat apabila nyai juga berperan aktif di lingkungan pesantren. Citra yang tinggi juga dapat diperoleh jika nyai memiliki kemampuan untuk memimpin, pengetahuan dan pengalaman yang cukup, serta bisa mengambil keputusan dengan tepat, untuk itu selayaknya segala syarat kepemimpinan sudah selayaknya dimiliki nyai untuk memimpin pesantren.

$$
\text { Selain sebagai pemimpin }
$$
pesantren, nyai juga mempunyai peran lain, nyai adalah guru, teladan, dan sumber nasihat bagi para santri ${ }^{9}$. Peranan yang tepat dijalankan oleh seorang nyai adalah sebagai mediator dan pendidik ${ }^{10}$. Sebagai guru atau pendidik, biasanya nyai akan mengajarkan berbagai disiplin ilmu keagamaan. selain itu saat ini nyai perlu memberikan pemahaman dan

9 Ema marhumah, Kontruksi sosial Gender di Pesantren, (Yogyakarta: LKis, 2010), hlm. 07 ${ }^{10} \mathrm{Ibid}, 136$ 
realitas,

kecenderungan

dan permasalahan global, memasukkan materi-materi yang berhubungan dengan kesanggupan berkiprah dan menjawab tantangan zaman. Misalnya, santri sudah saatnya bebicara dalam persoalan kemanusiaan, ekonomi, pelindungan alam, yang sebenarnya juga merupakan inti dari ajaran suci al Qur'an.

Peran sebagai teladan atau uswah juga merupakan sesuatu yang penting. Teladan untuk diikuti segala tingkah laku dan perbuatannya. Hal ini merupakan kelanjutan dari peran nyai sebagai guru. Dalam filosofi jawa guru merupakan sesuatu yang agung yang harus diikuti segala tingkah lakunya. Untuk itu nyai harus menjadi tauladan yang baik bagi santrinya, dan harus berkarakter luhur, karena pengajaran dengan tingkah laku lebih mengena daripada pengajaran dengan perkataan. Apalagi jika melihat tujuan utama pengajaran di pesantren bukan semata-mata ilmu pengetahuan agama, tetapi juga riyadhoh agar terbiasa hidup sederhana, menjunjung tinggi moral, menghargai nilai spiritualitas dan kemanusiaan, terbangun sikap dan tingkah laku yang jujur yang tujuannya adalah semata-mata mencari ridho Allah ${ }^{11}$.

Peran nyai selanjutnya yang penting bagi santri adalah sebagai sumber nasehat. Nasehat dalam berbagai bidang kehidupan. Ini tidak lepas dari kontruksi pesantren yang merupakan sebuah keluarga besar dengan puluhan bahkan ratusan atau ribuan anggota keluarga, ibarat keluarga nyai sebagai ibu dan santri sebagai anaknya. Dalam kehidupan, ibu mempunyai kedekatan yang lebih dengan anak-anaknya, begitu pula nyai, seharusnya tiada sekat antara nyai dengan santri, tapi nyai haruslah mengerti setiap problem yang dihadapi oleh santrinya, serta berusaha untuk membantu penyelesaian dari problem tersebut. Nyai "haruslah mencintai muridnya seperti mencintai dirinya sendiri, memperhatikan kebaikan siswa, dan menjalin hubungan akrab dengan santri layaknya anak sendiri seperti rasa kasih sayang, menolong, berbuat kebaikan, sabar terhadap segala kelakuan siswa $^{12}$.

12 Ema marhumah, Kontruksi sosial Gender di Pesantren, (Yogyakarta: LKis, 2010), hlm 85 
Strategi Pengelolaan Pesantren AL otomatis kemampuan kitab kuning dari Hajar mereka cukup mumpuni. Selain alumni

Pesantren Al Hajar merupakan pesantren salaf, pengasuh juga pesantren yang berada di dusun merupakan aktivis organisai Kapurejo, desa Pagu, kecamatan Pagu, kemasyarakatan, terutama sosok ibu Kabuoaten Kediri. Pesantren ini berdiri Nyai yang merupakan pengurus kurang lebih tahun 1980 an. Cikal bakal Cabanag Nahdlatul Ulama, sering pesantren ini, awalnya adalah sebuah berdakwah baik dalam skala kecamatan pengajian rumahan yang diasuh oleh Kyai Ahmad Najmuddin dan Ibu Mahmudah. Anak-anak dari desa setempat menimba ilmu kepada kyai Ahmad dan Ibu Mahmudah setiap harinya. Dengan bergulirnya waktu, semakin banyak santri yang ikut menimba ilmu, dan akhirnya memutuskan untuk bermukim. Nama Al Hajar diambil dari nama ibu dari pengasuh, yang bernama Siti Hajar. Siti Hajar sendiri merupakan menantu dari KH. Hasan Muhyi, mertua dari KH. Hasyim Asy'ari dari Kapurejo. Siti Hajar yang berasal dari Nganjuk, dinikahkan dengan KH. Moh. Ilyas, putra KH. Hasan Muhyi.

Pesantren al Hajar merupakan pesantren salaf dengan unsur-unsur sumber daya manusia yang bervariasi, mulai dari kyai dan ibu nyai yang alumni pesantren salaf, putra putrinya yang juga alumni pesantren salaf, sehingga maupun kabupaten, sehingga namanya cukup familiar di masyarakat terutama di kalangan kaum perempuan.

Pada awalnya pesantren al Hajar hanya merupakan pesantren dengan program diniyah ansich. Santri yang belajar di sini hanya berorientasi pada pengajian kitab kuning untuk memperdalam ilmu agama, dan pengajian al Qur'an bin nadzri dan bil ghoib, sehingga lama pendidikan di pesantren al Hajar akan tidak tentu, adakalanya santri bias menempuh pendidikan pesantren selama 5 tahun, adakalanya lebih ataupun kurang, tergantung dari kemampuan, dan kepuasan diri santri.

Tetapi mulai tahun 1998 peradigma pendidika di pesantren al Hajar mulai bergeser dengan adanya lembaga pendidikan formal yaitu Madrasah Tsanawiyah (MTs), dan Madrasah Aliyah 
pendidikan tersebut, orientasi belajar santripun berubah, kebanyakan santri akan belajar dengan berdasar waktu, menyesuaikan dengan program Mts dan MA, tidak lagi berorientasi pada pengajian kitab kuning. Dengan kondisi yang seperti itu, maka perubahan pun dilakukan oleh pesantren al Hajar, untuk tetap mempertahankan kualitas pesantren.

Tarjet pesantren adalah menjadi lembaga tafaqquh fid din, santri menguasai ilmu agama, mampu membaca kitab kuning, dan khatam al Qur'an, serta menyelesaikan pendidikan formal (MTs/MA), sehingga kelak dapat menjadi bekal untuk masa depan. Di sisi lain santri al Hajar sebagian besar adalah anak usia 12 sampai 20 tahun, usia ketika manusia mencari jati diri dan haus akan pengetahuan, maka strategi yang baik harus dilakukan pesantren untuk memenuhi target. Di sini peran pengasuh pesantren sebagai pengganti orang tua untuk mengarahkan mereka mencapai cita-citanya sangat penting. Tetapi karena sebagian besar santri pesantren al Hajar dalah perempuan, maka pendampingan dari pengasuh

laki-laki memberikan kepercayaan penuh kepada pengasuh perempuan untuk mengembangkan pesantren. Ada kerjasama yang harmonis dan kepercayaan yang tinggi dari pengasuh laki-laki atau kyai terhadap ibu nyai untuk mengelola pesantrennya. Dengan kepercayaan yang tinggi dari kyai, maka ibu nyai berusaha mengatur pesantren dengan baik.

Untuk menjalankan program pesantren, maka ibu Nyai membuat pengurus sebagai pelaksana program pesantren. Pengurus terdiri dari pengurus harian, dan pengurus ubudiyah, atau bidang pendidikan. Dalam pemilihan pengurus, ibu nyai langsung menunjuk santri yang paling senior, memiliki pengetahuan agama yang baik, dan dianggap mampu menjalankan manajemen pesantren.

Selain membentuk kepengurusan, kurikulum juga membawa peranan penting untuk keberhasilan progam pesantren. Untuk itu pesantren al Hajar membentuk madrasah Dinyah dengan dua tingkatan yakni tingkat ula untuk kategori pemula yang ditempuh selama 3 tahun dan tingkatan wustho kategori dewasa, juga ditempuh selama 3 tahun, tercebut tercapai, kyai sebagai pengasuh pengajian sorogan al Qur'an, sorogan 
kitab kuning, pengajian mingguan, dan ekstrakurikuler.

Peranan ibu Nyai dalam kurikulum madrasah ini begitu mencolok, baik dalam madrasah diniyah, sorogan, dan pengajian mingguan. Ibu nyai menentukan sendiri jenis kitab yang akan diajarkan pada santri, yang dipandang sesuai dengan kebutuhahn santri, karena Ibu nyai beranggapan dirinyalah yang lebih tahu akan kebutuhan santri. Ibu nyai nyai juga langsung terjun untuk mengisi kegiatan terssebut.

Demi kelancaran pesantren yang dipimpinnya, ibu Nyai melakukan pengelolaan dan strategi di pesantren. Hal hal yang dilakukan, adalah musyawaroh di awal tahun ajaran baru, meliputi perencanaan madrasah diniyah, pengajian al Qur'an dan pengajian kitab kuning. Selain itu juga membahas mekanisme penerimaan santri baru, menentukan seleksi kemampuan santri. Setelah kemampuan santri terdeteksi, barulah diadakan pengelompokan sesuai dengan kapasitas kemampuan masing masing. Hal lain yang masuk dalam perencanaan adalah perencanaan tata tertib bagi santri, dan pemberian prestasi bagi santri, untuk memacu semangat, dan kreatifitas santri, dan memberikan sanksi bagi santri yang melanggar peraturan.

Jika semua perencanaan telah dilaksanakan dalam kehidupan seharihari dipesantren, ibu Nyai selalu memberikan pengawasan dan motivasi dengan secara langsung terjun ke santri, bergaul dengan santri, memberikan motivasi dalam kehidupan sehari-hari, misalnya dalam pengajian kitab kuning yang langsung diasuhnnya, ibu nyai memberikan keterangan yang motivasi santri untuk lebih baik, untuk belajar, memberikan argument yang mengena pada diri remaja.

Pengawasan juga dilakukan oleh nyai, melalui pengurus, mulai ketua sampai pengurus bidang, sehingga jika ada pelanggaran, maka akan diambil sanksi yang bersifat mendidik yang lebih dahulu dikonsultasikan dengan pengasuh. Sanksi yang diberikan, misalnya berupa teguran, hafalan sejumlah pelajaran diniyah, ataupun membersihkan lingkungan pesantren. Jika dengan sanksi yang diberikan, tidak ada efek jera, maka akan dilakukan pemanggilan terhadap wali santri. 


\section{Kepemimpinan Perempuan Pesantren}

Teori kepemimpinan menyebut 5 gaya dalam model kepemimpinan. Walaupun gaya kepemimpinan bisa berubah menurut situasi dan kondisi, tetapi kecenderungan gaya akan tampak dalam kehidupan sehari-hari. Dalam pesantren al Hajar, kepemimpinan perempuan terletak di tangan ibu Nyai. Kepemimpinan tunggalnya mewarnai kehidupan pesantren setiap harinya. Gaya kepemimpinan yang tunggal dan kemampuan individual yang mumpuni mampu menciptakan situasi yang membuat element pesantren tunduk kepadanya. Kepatuhan dan ketundukan itu tampak dari perkataan "nggih" yang seringkali muncul dari bawahannya, walaupun itu dari anak kandungnya, juga dari pengurus pondok yang selalu menunggu keputusan ibu nyai dalam perencanaan, kegiatan, dan penyelesaian konflik di pesantren. Setiap musyawaroh yang selalu dipantau langsung oleh ibu nyai, setiap peserta kebanyakan hanya menjadi pendengar, dan menunggu keputusan yang keluar dari ibu nyai, kalaupun ada usulan, tetapi kecenderungan lebih memilih keputusan
Gaya kepemimpinan ibu nyai cenderung otoriter, mementingkan hasil kerja. Sikap ini bisa jadi timbul karena melihat kondisi bawahan yang memerlukan bimbingan, santri pada tahap usia remaja, masih labil dan belum banyak mengerti ajaran agama memaksa ibu nyai bersikap otoriter. Apalagi dengan keterbatasan waktu, kebanayakan santri akan boyong setelah menamatkan pendididikan Aliyah, memaksa ibu nyai juga harus bekerja keras menyesuaikan target kurikulum pesantren.

Untuk mencapai target yang dibuat pesantren, ibu nyai langsung turun tangan sebagai pendidik di pesantren, mulai menjadi guru sorogan al Qur'an di pagi hari, dan membacakan beberapa jenis kitab seperti kifayah al Atqiya', Idatun Nasyi'in, Minhatul Mughits, Ummul Barohin, dan tafsir Jalalain secara bergantian dalam setiap harinya. Selain itu juga ada kitab yang Irsyadul Ibad yang dibacakan setiap minggunya.

\section{Penutup}

Segala peran yang dilakukan oleh pengasuh perempuan apabila dilakukan dengan maksimal akan menghasil output yang baik. Ketika pengasuh perempuan 
merupakan sosok yang berkualitas, dan diberi kepercayaan yang tinggi, maka rasa tanggung jawab sebagai akan tumbuh. Pengasuh perempuan bukan hanya sebagai pelengkap, tetapi juga merupakan bagian dari keberadaan pesantren.

Saran yang direkomendasikan penulis, agar pengasuh memperbaiki manajemen pesantren, jangan hanya terpaku pada figure ketokohan. Untuk perekonimian pesantren yang selama ini menjadi kendala, diharapkan pesantren lebih lebih kreatif mengembangkan program ekonomi pesantren, agar pesantren bisa menjadi pesantren yang mandiri.

\section{Daftar Pustaka}

Arifin, Zaenal. "Efektifitas Kepemimpinan Lembaga Pendidikan Islam di Pesantren." Tribakti: Jurnal Pemikiran Keislaman 27.1 (2016): 40-64.

Dhofier, Zamakhsyari, Tradisi Pesantren Jakart: LP3S, 1982

Faiqoh,Nyai Ageng PErubahan PEsanren Jakarta: Kucica, 2003

Keating,' Charles J., Kepemimpinan Teori dan Pengembangannya, Yogyakarta: Kanisius, 1986
Marhumah, Ema, Kontruksi sosial Gender di Pesantren, Yogyakarta: LKis, 2010

Moeloeng, Lexy J., Metodologi Penelitian Kualitatif, Bandung: Remaja Rosdakarya, 2010

Susilo, Suko Memahami Kepemimpinan, Surabaya: Jenggala, 2005

Syam Nur," Kepemimpinan dan Pengembangan Pondok PEsantren", dalam A Hilmim dkk (ed), Manajemen PEsantren, Yogyakarta: Pustaka PEsantren, 2005

Susilo, Ahmad, Strategi Pengembangan Pondok Pesantren, Jakarta: Moyo SEgoro, 2003

Susilo, Suko. "SEJUMLAH MITOS SEPUTAR KEPEMIMPINAN: Tinjauan Psikologi Sosial." Tribakti: Jurnal Pemikiran Keislaman 24.1 (2013). 